\title{
“Who Will Change New Lamps for Old Ones?": Aladdin and His Wonderful Lamp in British and American Children's Entertainment
}

\author{
Jennie MacDonald
}

On Tuesday, the 2oth of April, 1813, the dramatic reviewer for The Morning Chronicle reported on the previous night's opening of Theatre Royal Covent Garden's new "Melo-Dramatic Romance" by actor/playwright Charles Farley, Aladdin; or, The Wonderful Lamp: ${ }^{1}$

"Whoever has read the Arabian Nights Entertainment $^{2}$ (and who has not) cannot fail to recollect with pleasure the story of Aladdin, and the Wonderful Lamp.... The machinery of the piece, on which all the effect of a tale of enchantment depends, was admirably worked, and seemed tangibly to perform the fabled operations of magic. This was aided by a splendour and magnificence truly oriental, and which threw over the spectacle a most imposing grandeur. The tout ensemble was certainly captivating, and it would be difficult for the sternest critic to remain unmoved by the scenes of enchantment passing before his eyes..."3

1 The review refers to the play using a slightly different title, Aladdin, and the Wonderful Lamp. The play mentioned here is Charles Farley's Aladdin; or, The Wonderful Lamp, first performed on April 19, 1813 at Covent Garden Theatre but not printed until 1836. John Larpent Plays, LA1766, The Huntington Library.

2 Robert Irwin notes that Jonathan Scott's translation, "the Arabian Nights Entertainments, which appeared in 1811, was the first literary translation into English of [Antoine] Galland's" early eighteenth-century French compilation of the tales. For "[w]hoever has read the Arabian Nights Entertainments (and who has not)," Scott's recent version may have been familiar. See Robert Irwin, The Arabian Nights: $A$ Companion, 2nd ed. (London: I.B. Tauris, 2009), 22.

3 "Covent-Garden Theatre," The Morning Chronicle, April 20, 1813,3 .
Thanks to the familiarity of the play's origin story, theatrical spectacle presenting a "truly oriental" wonderland of scenery and special effects, and an affecting cast, the reviewer concluded, " $t$ ] he Managers having thus got possession of the Wonderful Lamp, it will probably be productive to them of considerable profit." Over the next six weeks, the play was presented thirty nights and consistently revived through to the end of 1815 . During subsequent revivals that saw it performed well into the mid-nineteenth century, it found additional life in the booming juvenile drama and its companion industry, the toy theater, and contributed to later nineteenth-century reconceptions of the tale that can still be found in residual form in modern British pantomime. This chapter, therefore, will examine ways in which the Aladdin tale was interpreted for visual consumption in England during the Romantic era, and how an "Arabian" idealized look could be seen in stage costumes, props, and scenery, finding expression in children's public and domestic entertainment in England and America well into the twentieth century.

The 1813 production of Aladdin; or, The Wonderful Lamp reaches back to the early eighteenthcentury translation and publication of the Arabian Nights' Entertainments in England, comments on its own cultural moment, and anticipates later renditions of the tale. It functions as a compass rose event, a term I have borrowed from Paula Findlen: "the global lives of things emerge within and at the interstices between local, regional, and long-distance trading networks. Much like the compass roses on a medieval portolan, networks only exist when a connection is made-no line touches another without a node that creates the 
point of contact which is also the moment of exchange." In the staged play, the lamp is represented by a physical prop supposed to resemble an ancient oil lamp; as a material object, the lamp functions as a node which creates points of contact when transferred from one character to another as a possession. One character's possession of the lamp also indicates its absence from other characters' possession, particularly of those who desire it. When the lamp moves from one character to another, it takes with it wish-fulfilling power, expressed in material objects and wealth. The Morning Chronicle's view of Covent Garden's new play as a "Wonderful Lamp" serves not only as a clever metaphor but also as a way of transforming the production itself into a node, or a magical vessel which, just like Aladdin's lamp, can be transferred through time and space in revivals and adaptations, participating in a network of literature, performance, commodification, and cultural significance. The "Wonderful Lamp" ascription abstracts from literature the idea of Aladdin's lamp being both a socially-resonant symbol and a material object capable of metamorphosing from a lamp as a stage prop to a theatrical production itself.

Long before the Covent Garden production, however, Aladdin's story knew many iterations and participated in other compass rose events. As Findlen points out, "[e]ach exchange" of material goods "becomes an opportunity to observe how things metamorphose from one society to another." A multiplicity of exchanges builds a network between cultures through geographical space, like the rhumb lines on a portolan chart, making possible connections through time. As with many other literary tales, subsequent retellings via translation and adaptation to other media resulted in altering and streamlining elements of this early version.

4 Paula Findlen, "Afterword: How (Early Modern) Things Travel," in The Global Lives of Things: The Material Culture of Connections in the Early Modern World, ed. Anne Gerritsen and Giorgio Riello (Abingdon: Routledge, 2016), 244.

5 Ibid.
Through its adaptation into dramatic form for children in England and America over subsequent decades, Aladdin; or, The Wonderful Lamp underwent many changes, including simplification of incidents and scenes, as well as conflation, combination, elimination, and addition of characters. In his article, “A Thousand and One Nights at the Movies," Robert Irwin notes that "skilled scriptwriters do not merely excise and abridge, they also find ways of saying things visually." ${ }^{6}$ Over time, locations, character names, and design elements of Aladdin's story have changed in response to shifting aesthetic, cultural, and political interests. The roles of Aladdin, the lamp, its genie, the magician, and the princess have remained firmly attached to the story, however, as have crucial plotlines concerning how the lamp was obtained, how it was stolen, its recovery, and the riches it bestows as a wish-fulfilling device.

In Representing China on the Historical London Stage: From Orientalism to Intercultural Performance, Dongshin Chang extends Edward Said's concept of Orientalism, ${ }^{7}$ which focused on European, British, and American socio-political constructions of Arabic and Islamic cultures, and examines the incorporation of Chinese elements in British Orientalist theatrical productions. ${ }^{8}$ The epilogue traces the developments of Aladdin's story as a vehicle for expressing "the evolving, interculturated depictions of China as a feminized and material attraction," from early British theatrical renderings of plays set in Chinese locations to modern British pantomime, or "panto" versions. Given the nominal and visual flourishes presented in the 1813 Covent Garden production of Aladdin; or, The Wonderful Lamp and the toy theater versions it engendered, assigning a Chinese cultural identity to the play is tempting. As Chang points

\footnotetext{
6 Robert Irwin, "A Thousand and One Nights at the Movies," Middle Eastern Literatures 7, no. 2 (2004): 224. See Edward W. Said, Orientalism (New York: Random House, 1994).

8 Dongshin Chang, Representing China on the Historical London Stage: From Orientalism to Intercultural Performance (New York: Routledge, 2015), 1.
} 
out, however, "the lack of translated Chinese dramatic texts, and the associated lack of understanding of Chinese theatre" in early nineteenth-century Britain, "resulted in a situation in which British theatre practitioners could not have drawn on Chinese dramatic literature and aesthetic principles for textual and conceptual inspiration even if they had wanted to." ${ }^{\prime 9}$ Concerning today's nowtraditional "Chinesely British" pantos adumbrated by Farley's early play, Chang finds "[most] notable" the "interculturalization of [the tale's] Chinese locale with characters in Muslim names, which creates an impossible Oriental setting that clearly demonstrates the tale's fictitiousness." ${ }^{10}$ In the present discussion, Chang's terms, "interculturalize" ("the act of creating a relationship between elements that belong to disparate cultures"11) and "interculturation" ("the ongoing process in which disparate cultural elements are interculturalized over a substantial period of time"12) are used in order to encompass myriad geographical locations and references. I have taken a cue from Chang's response to Said's Orientalism to extend Chang's notion of interculturalizing to consider the multifaceted and culturally-blurring effect of combining elements from multiple cultures in the creative industries involved in handing down Aladdin's story to nineteenth- and twentieth-century children. Such performances combined British and American conceptions of the fantastic not only with Chinese elements but also with Arabic, Ottoman, Indian, Persian, Egyptian, and northern African elements. Chang's term "Chinaface" ("the creative choice to represent China on a visual, formal level as opposed to a textual, conceptual level"13) is here broadened to "Orientalized look" to discuss multiple cultural influences observable in character prints and toy theater sheets depicting Aladdin; or, The Wonderful Lamp.

\begin{tabular}{ll}
\hline 9 & Ibid., 10. \\
10 & Ibid., 182. \\
11 & Ibid., 2. \\
12 & Ibid. \\
13 & Ibid.
\end{tabular}

In the cultural transmission of Aladdin's story from its introduction as a lesser tale in a compendium of Arabian folklore to the Western cultures of Great Britain and America, its central object, Aladdin's wonderful lamp, with its power of wishfulfillment, has played a key role in making the story an attractive property for children's dramatic entertainment from the early Romantic era to the twentieth century. ${ }^{14}$ In this process, the tale was represented in ways that gestured at authenticity but promoted an exotic and magical image of an interculturalized "Arabia" which drew upon disparate aesthetic and cultural practices and had little to do with a specific, geographically identifiable place.

\section{Aladdin's Lamp in the West: Eighteenth- Century Translations and Early Dramatic Adaptations}

The French scholar and archeologist Antoine Galland (1646-1715) is the central figure responsible for introducing the remarkable folktales of medieval Arabia, northern Africa, India, and adjacent regions to the West. Based on a fourteenth-century Syrian manuscript, Alf Layla Wa-Layla (One Thousand Nights and One Night), and supplemented by nine additional tales, Galland's translation, Les mille et une nuits (One Thousand and One Nights), appeared in twelve volumes published in Paris over the period 1704-1717. The first part of "L'histoire d'Aladdin, ou la lampe merveilleuse" appeared at the end of volume nine, with the conclusion at the beginning of volume ten. Traditionally referred to as an "orphan tale," along with "Ali Baba and the Forty Thieves," "The Story of Sindbad the Sailor," and several others, "Aladdin; or, The

14 For more on the development of the tale in English pantomime, see Chang and also Millie Taylor, "Continuity and Transformation in Twentieth-century Pantomime," in Victorian Pantomime: A Collection of Critical Essays, ed. Jim Davis (Hampshire: Palgrave Macmillan, 2010), 185-200. 
Wonderful Lamp" was not part of the original Syrian collection. Madeline Dobie indicates Galland's acquaintance "with a Syrian Maronite whom he calls 'Hanna,' and later 'Jen Dippi,"” who "told him a number of beautiful Arab tales ... widely presumed to derive from Syrian oral tradition, though the possibility remains open that they were of his own invention." 15 More recently, Paulo Lemos Horta has celebrated the discovery of Hanna Diyab's memoir, "long neglected in the collection of the Vatican Library," and examined elements of Diyab's travels that suggest, if not his own invented contributions to the tales he told to Galland, at least a personal sympathy with Aladdin's struggles that might have prompted him to recount it. ${ }^{16}$ The story of Aladdin was one of these tales. Although the first English translation of the book was entitled Arabian Nights' Entertainments, emphasizing the geographical origin of Scheherazade's tales in Arabia, Aladdin's story is located in China and Africa.

In the tale, the youth Aladdin is a goodfor-nothing scamp whose father, Mustapha, dies of despair that his son will ever make something of himself. ${ }^{17}$ An African magician, whose forty years

15 Madeline Dobie, "Translation in the Contact Zone: Antoine Galland's Mille et une nuits: contes arabes," in The Arabian Nights in Historical Context: Between East and West, ed. Saree Makdisi and Felicity Nussbaum (Oxford: Oxford University Press, 2008), 35.

Paulo Lemos Horta, introduction to Aladdin: A New Translation, trans. Yasmine Seale (New York: Liveright, 2019), xi. See also Paulo Lemos Horta, Marvellous Thieves: Secret Authors of the Arabian Nights (Cambridge, CT: Harvard University Press, 2017).

17 For the purposes of this discussion, the character names are presented as in the first English translation titled Arabian Nights' Entertainments (1706-1712), although spellings varied widely over the subsequent two centuries of adaptations and translations. The princess's name, in particular, was subject to many changes and later replaced with completely different names, which are used when discussing specific adaptations. The Aladdin story title has also been variously rendered for plays, and within individual plays character names had multiple spelling variants, due partly to of study have pointed him to a magic lamp hidden in a cave near the Chinese city where Aladdin lives, arrives to procure the lamp. He has been warned, though, that it can only be retrieved by an innocent, and he employs Aladdin in this task under the pretense of being the boy's long-lost uncle, brother of his father. Aladdin accompanies his "uncle" to the cave, where the magician outlines a series of intricate instructions on how to retrieve the lamp and gives him a ring for protection. Aladdin descends into the cave and passes through a garden of beautiful trees hanging with fruit made of jewels. Upon a terrace-walk, the magician instructs him: "you will see a niche before you, and in that niche a lighted lamp. Take the lamp down and put it out; and when you have thrown away the wick, and poured out the liquor, put it in your breast, and bring it to me."18 When Aladdin attempts to exit the cave, his pockets full of jewels weigh him down and he is unable to give the lamp to the magician, who pushes him back down, causing him to be trapped in the cave. When Aladdin asks to be released from the cave, the genie of the ring appears and grants his wish. After returning to his widowed mother, Aladdin expresses an interest in the sultan's daughter, Princess Badroulboudour, although she is supposed to be marrying the son of her father's vizier. Aladdin's mother is the one who first rubs the lamp, releasing its genie. ${ }^{19}$ Aladdin asks the genie for wealth and a magnificent

printing errors and partly to the "exotic" or "foreign" nature of these names.

Arabian Nights' Entertainments, ed. Robert L. Mack (Oxford: Oxford University Press, 1998), 658.

19 Galland's translation and early dramatic adaptations present several genies of the lamp that seem indistinguishable from one another rather than the single genie of later versions. The magical ring and its genie also disappeared from later versions. Of note is the distinction of the genies' capabilities. The genie of the ring's magic is limited to magically transporting Aladdin from place to place, while the genie(s) of the lamp are able to magically create physical objects for him, as well as move the palace and its inhabitants to and from a faraway country. 
palace in order to prove himself a worthy suitor and persuades his mother to convey to the sultan his wish to marry the princess. After thwarting the vizier's son's marriage to the princess, Aladdin is seen to be learning wisdom and generosity, and the two are wed.

The magician, however, has not forgotten the lamp. In the guise of a simple trader, he appears in the street near Aladdin's palace, calling, "Who will change new lamps for old ones?"20 Aladdin is away hunting, but the princess, thinking it a good joke, tells her servant to bring his old lamp and obtain a new one from the foolish merchant. At last in possession of the lamp, the magician orders its genie to carry away the palace and the princess to a faraway country. Aladdin, however, still has the ring of protection, and its genie magically conveys him to the palace. Once there, Aladdin provides the princess with poison, which she gives to the magician in a cup of wine. Upon the magician's death, the genies of the lamp return the palace to its rightful place where Aladdin and Badroulboudour will live happily ever after.

Following the publication and success of Galland's Les mille et une nuits, in a key compass rose event and alongside other European translations, an anonymous English translation titled Arabian Nights' Entertainments, also known as the "Grub Street" edition (1706-1721), soon appeared. British reprints, adaptations, chapbooks, and serializations in newspapers like Parker's London News proliferated shortly thereafter, ensuring that the tales of the Arabian Nights' Entertainments took up residence in eighteenth-century England's popular imagination. ${ }^{21}$ Aladdin's lamp and its genie readily served as literary shorthand for wish-fulfillment, as illustrated in Horace Walpole's letter of July 1, 1782, to his long-time friend, George Harcourt: "I did but mention the head [portrait] of Addison-and

\footnotetext{
20 Mack, Arabian Nights' Entertainments, 703.

21 See Nicholas Seager, "The Novel's Afterlife in the Newspaper, 1712-50," in The Afterlives of Eighteenth-Century Fiction, ed. Daniel Cook and Nicholas Seager (Cambridge: Cambridge University Press, 2015), 111-32.
}

I found it on my table. I must have Aladdin's lanthorn, without knowing it, and you are certainly one of the génies subservient to it, that obey in a twinkling whatever-but no, for once, Mr. Génie, you are mistaken. I not only did not order you to send Addison, but you must transport it back, or I will."22 Walpole's playful commentary casting Harcourt as a genie of the lamp exemplifies David A. Brewer's notion of "detachability": "the ways in which print and theater ... could make a character seem detachable from his originary context and the desire to figure the virtual community which forms around such a character as a network of friends bound together through that character."23 Not only can the genie function as a "detachable" character who may be portrayed by Walpole's acquaintance, but "Aladdin's lanthorn" also can be "detachable" as an object whose power is summoning and conveying wishes to the genie, who carries out the magic. The term "Aladdin's lamp," more generally, has come to signify the whole of the story, as well as the concept of wish fulfillment. Moreover, as a literarily "detachable" character in possession of a literarily "detachable" object, Aladdin and his magical lamp started a process of constructing "Arabia" in the Western imagination as a place of wonder, exoticism, and transport. ${ }^{24}$

22 Horace Walpole, "To Harcourt, Monday 1 July 1782," in The Yale Edition of Horace Walpole's Correspondence, ed. W.S. Lewis, A. Dayle Wallace, and Robert A. Smity (New Haven, CT: Yale University Press, 1973), 35: 516.

23 David A. Brewer, The Afterlife of Character, 17261825 (Philadelphia: University of Pennsylvania Press, 2005), 79 .

24 A number of nineteenth-century translations arose to supersede the Grub Street edition. These included Jonathan Scott's 1811 literary translation; Edward Lane's expurgated version (1840), which was often repackaged in children's editions; John Payne's The Book of a Thousand Nights and One Night (1882); and Sir Richard Francis Burton's The Book of the Thousand Nights and a Night (1885-1888). Alongside these editions rose an industry in editions specifically for children, which were then adapted into hybrid book toys, such as the Pantomime Toy Books series issued by McLoughlin Bros. in America. 
The magical element of the story embodied by Aladdin's lamp made it a welcome and even subversive entrant into the Enlightenment's ardent pursuit of fact, reason, and scientific investigation. As Marina Warner has noted, the popularity of the Arabian Nights tales during the Age of Reason was due in large part to their embrace of magic, which "follows processes inherent to human consciousness and connected to constructive and imaginative thought.... At one pole (myth), magic is associated with poetic truth, at another (the history of science) with inquiry and speculation.... Magical thinking structures the processes of imagination, and imagining something can and sometimes must precede the fact or the act; it has shaped many features of Western civilization." ${ }^{25}$

As Romanticism emerged from Enlightenment thinking, the magical quality of Aladdin's lamp also made the story a ready vehicle for the theater in forms that included pantomime, romantic melodrama, and "A Fairy Opera." ${ }^{26}$ Leo Hughes notes that the "chief attraction of pantomime from the beginning had of course been scenic display, especially as assisted by 'magic.' It is not surprising, therefore, that at Theatre Royal Covent Garden John O'Keeffe started Aladdin and his 'wonderful lamp' on their long career on the day

25 Marina Warner, Stranger Magic: Charmed States and the Arabian Nights (Cambridge, MA: Harvard University Press, 2011), 22-23.

Burton comments, "Alaeddin [sic] has ever been a favourite with the stage. Early in the present [nineteenth] century it was introduced to the Parisian opera by M. Etienne, to the Feydeau by Théaulon's $L a$ Clochette; to the Gymnase by La Petite-Lampe of MM. Scribe and Melesville, and to the Panorama Dramatique by MM. Merle, Cartouche and Saintine (Gauttier, vii. 380)" (51). For details, see Richard Francis Burton, "Alaeddin; or, the Wonderful Lamp," in Supplemental Nights to the Book of the Thousand Nights and a Night with Notes Anthropological and Explanatory (London: Privately Printed by the Burton Club, 1887), 3:51-91. For some reason, Burton neglects to mention any nineteenth-century English productions. after Christmas 1788,27 a career that would carry them directly into the heart of the emerging market for children's entertainment, where stories infused with magical elements were a welcome and natural fit. Unfortunately, O'Keeffe's version of Aladin; or, The Wonderful Lamp survives only in its libretto; ${ }^{28}$ however, the libretto indicates an interest in adhering to an "Arabic" setting with "the magic lamp ... hidden in 'Arabia's spice vales,' in 'a valley dark and deep"'29 rather than setting the scene near Aladdin's home, in a Chinese location. Changing the setting from China to an idealized Arabia rendered in the sensuous and sublime terms of Romanticism imbued the name "Arabia" with qualities of wonder and exoticism, effectively interculturating the theatrical representation of Arabia while also claiming to present an "authentic" view of it as a specifically "Arabian" Nights' Entertainments.

Subsequent theatrical iterations also demonstrated a similar interest in affiliating the tale with its "Arabian" literary origin through interculturalized character and place names, cultural references, and theatrically powerful visual signifiers, such as settings and costumes conveying an Orientalized look. To exemplify, a manuscript copy of Alladin; or, The Wonderful Lamp, a Romantic Drama in Two Acts, held by the John Larpent Plays collection at the Huntington Library, offers a different version from that of O'Keeffe's and its descendants. Written for the Theatre Royal, Norwich, and licensed on 4 April 1810, Alladin is set in "Bagdad" [sic], although Alladin's home is a room decorated

27 Leo Hughes, The Drama's Patrons: A Study of the Eighteenth-Century London Audience (Austin: University of Texas Press, 1971), 160.

28 See John O'Keeffe's The Recitatives, Airs, Choruses, \&c. in Aladin; or, The Wonderful Lamp. A Pantomime Entertainment. Performed at the Theatre-Royal, CoventGarden. The Music Composed by Mr. Shield, and ed. (London: Printed for T. Cadell, 1788), 8.

29 Chang, Representing China on the Historical London Stage, 182. 
"in the Turkish Style."30 Moreover, the Cave of Albumanzor is located "westward of Bagdad" in a "deep Valley surrounded with stupendous Rocks" where the "Lamp of Idmon"31 is also found. Most character names are generically "Arabic": these include Alladin (spelled either as "Aladin" or "Aladdin"), his mother Zulima, Princess Palmira, Sultan Mahmoud, and the genie and/or fairy Abra. ${ }^{32}$ Various Arabian-type officials also appear: an Imam, an Officer of the Divan, Janissaries, and Vizier Usoph and his son, Solim. Several characters make appeals to Allah, but in this confection of Arabian wonder, Romantic sublime, and English fairy tale, it is the Fairy Abra who ultimately restores order and returns the lamp to Alladin.

On the 29th of April, 1826, Drury Lane premiered George Soane's new opera, Aladdin; or the Wonderful Lamp, A Fairy Opera, with music by Henry Rowley Bishop. The characters included Aladdin, the Schah of Persia, Mourad (an Enchanter), Zeenab (Aladdin's mother), and Nourmahal (the Schah's sister whom Aladdin marries). Three Genii of the Lamp and one Genius of the Ring carried out the magic. The settings included the city of "Ispahan" (a theatrical invocation of Isfahan, in Iran) and an ambiguous "African desert." As Kristin Tetens comments, "[t]he audience of Bishop's opera is never allowed to forget that the world of Aladdin is an Eastern - specifically a Muslimworld," that is, a "Muslim world" as interpreted by

Alladin; or, The Wonderful Lamp, a Romantic Drama in Two Acts, 4 April 1810, Norwich, John Larpent Plays LA1623, The Huntington Library, 39 (hereafter cited as Norwich MSs).

$31 \quad$ Ibid., 17. The "Lamp of Idmon" probably refers to Greek mythology, where a number of individuals are named "Idmon." A likely source figure is the seer Idmon, or "the knowing one," who accompanied the Argonauts and was Apollo's son.

The Enchanter is inexplicably called Olmosnooko, and he is attended by Trombollo (possibly an Italian name), "a discarded Servant of the Genii," who befriends Alladin. Zulima also has a daughter, Pyscho (also spelled "Psycho"), around whom a secondary love story revolves. the opera's English author: "[ $\mathrm{t}]$ he Prophet $\mathrm{Mu}$ hammed's name is invoked constantly and Allah's protection is sought at every turn."33 Various other linguistic turns signify "Muslim" speech and concerns, resulting in a dramatic vision of "Arabia" in which religion, alongside magic and exotic visual imagery, contributed to the fanciful and culturally "other" image of the place.

Unlike Soane and Bishop's unfortunate opera, ${ }^{34}$ however, revivals of Farley's 1813 grand Romantic spectacle fared far better and introduced new elements that would prove complex and enduring, particularly in the realm of children's entertainment. As a compass rose event, its debut showcased and capitalized on an intersection of Romantic sensibilities, a vogue for antiquarianism, and the incalculable "Grimaldi effect" on character physicality, comedy, and pathos. ${ }^{35}$ It also anticipated the rise of moral and fantasy stories for children. Part of this production's lasting legacy is due to its participation in an experimental and invaluable record of theatrical history: the juvenile drama (i.e., play scripts for children adapted from stage versions) and its visual adjunct, the toy theater.

\section{$2 \quad$ Aladdin's Lamp and Children's Entertainment in the Romantic Era}

As Bridget Orr has observed, "[t]heatrical versions of tales from the Thousand and One Nights have

Kristin Tetens, "Scheherazade on the English Stage: The Arabian Nights' Entertainments and the Georgian Repertoire," The Victorian Peeper: Nineteenth-Century Britain through the Looking Glass (blog), October 1, 2016, http://victorianpeeper.blogspot.com/2015/03/scheherazade-on-english-stage-arabian.html. Despite its ambitious staging and creators' reputations, the opera was poorly received and closed after only ten performances. Joseph Grimaldi (1778-1837) was an English actor whose buoyant and pathetic development of the popular Harlequinade pantomime role of Clown has indelibly marked subsequent portrayals of this ubiquitous character to the present day. 
been doubly occluded" from critical assessments of eighteenth-century and Romantic drama because "they were almost exclusively adapted into 'illegitimate' genres of pantomime, burletta, melodrama, spectacle, and romance, modes whose development they were crucial in shaping." ${ }^{36}$ These genres, Orr adds, have undergone a fertile transformation today: "Recent scholarship has suggested that, far from being trivial diversions, these extraordinarily successful theatrical forms created peculiarly modern modes of performance and spectatorship whose legacy is the cinema and mass audience of late modernity."37

If the adult versions of "illegitimate" drama have been "doubly occluded" from critical inquiry, it might be said that children's versions have been trebly occluded. ${ }^{38}$ Apart from classic studies by enthusiasts like George Speaight and A.E. Wilson, ${ }^{39}$ scholarly consideration of the juvenile drama, in general, and of the toy theater repertoire, in particular, has been fairly limited and inconsistent due, in part, to their original intended audience of children and critical dismissal of any material goods related to children's literature and entertainment, such as toys and games.

36 Bridget Orr, "Galland, Georgian Theatre, and the Creation of Popular Orientalism," in The Arabian Nights in Historical Context, ed. Saree Makdisi and Felicity Nussbaum (Oxford: Oxford University Press, 2008), 103. Ibid.

38 This is changing, however, with recent contributions to the history of children's literature and its many adaptive forms. See, for example, Marah Gubar, Artful Dodgers: Reconceiving the Golden Age of Children's Literature (Oxford: Oxford University Press, 2008); Popular Children's Literature in Britain, ed. Julia Briggs, Dennis Butts, and M.O. Grenby (Aldershot: Ashgate, 2008); and Victorian Pantomime: A Collection of Critical Essays, ed. Jim Davis (Hampshire: Palgrave Macmillan, 2010).

George Speaight, Juvenile Drama: The History of the English Toy Theatre (London: MacDonald, 1946) and The History of the English Toy Theatre (Boston: Plays, 1969); A.E. Wilson, Penny Plain Two Pence Coloured: A History of the Juvenile Drama (London: G.G. Harrap, 1932).
Toy theaters developed in the nineteenth century as adjuncts to the publication of play versions for children's performances and now appear as a kind of hybrid souvenir/coloring book/action figure sort of toy. They have their origins in the popular theatrical prints of the eighteenth century that portrayed actors costumed and posed in roles for which they were best known or were currently playing. William West and John Kilby Green are variously credited with first conceiving of sheets of theatrical characters, faithfully sketched by artists attending these performances. Very quickly, these character sheets started to be accompanied by sheets of scenery (including stage wings) and "tricks" (i.e., magic and special effects), purposebuilt miniature theaters, and playbooks abridged from professional scripts. A child-usually a boy-would be given or purchase for himself the sheets one by one or in sets, depending on his available funds. Sheets could be purchased already colored for two pence (two pennies), or plain (uncolored) for one penny. The child would paint with watercolors the figures and scenes, and then paste them to "card" (cardstock) and cut them out with a pen knife. A performance for family and friends would follow sometimes, with the child attempting to enact the characters, read the script, move characters about onstage, change the scenery, and carry out the special effects. This was often fraught with disaster and disappointment, and many children opted for the intricate and hard-won joy of decorating the sheets. For modern researchers, these ephemeral versions offer a visual history of the professional productions they were copied from, an insight into theatrical adaptation, and a view of childhood and "children's commodity culture - their books, their games, their theaterthat has enabled the popular culture of early modern Britain to survive today at all."40

The 1813 production of Aladdin; or, The Wonderful Lamp prompted the production of at least two

40 George Speaight with Brian Alderson, "From Chapbooks to Pantomime," in Briggs, Butts, and Grenby, Popular Children's Literature in Britain, 97. 


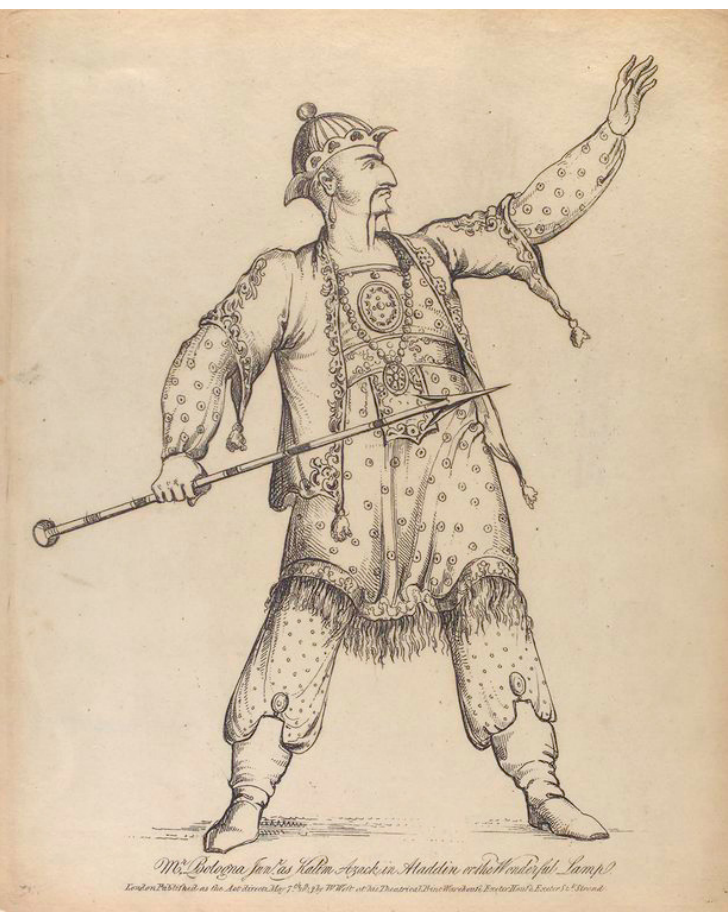

FIGURE 5.1 Mr. Bologna Jun-r as Kalim Azack in Aladdin, or The Wonderful Lamp.

theatrical prints, which are informed by interculturation and illustrate the Orientalized look of the tale's theatrical life: one of John (“Jack") Peter Bologna as Kalim Azack, the vizier's son betrothed to Badroulboudour, and one of the extraordinary pantomime clown Joseph Grimaldi as Kazrac, the magician's Chinese slave, who, disillusioned by the magician's cruel plans concerning the lamp, befriends Aladdin (figs. 5.1 and 5.2). The creation of this non-speaking role (Kazrac's tongue had been removed by the "Tartarian Hord" from whom the magician rescued him) added much to the play, besides giving both the magician and Aladdin an ally and a confidant. Interestingly, these two prints likely represent a notable scene in the play, certainly a favorite with children playing with a toy theater. The prints show Kalim Azack and Kazrac fighting while Aladdin follows the princess to the royal baths. The wealthy Kalim Azack is depicted wearing an elaborate ensemble: long embroidered tunic with fringe, short jacket with embroidery and tassels, full trousers tucked into boots, a sash,

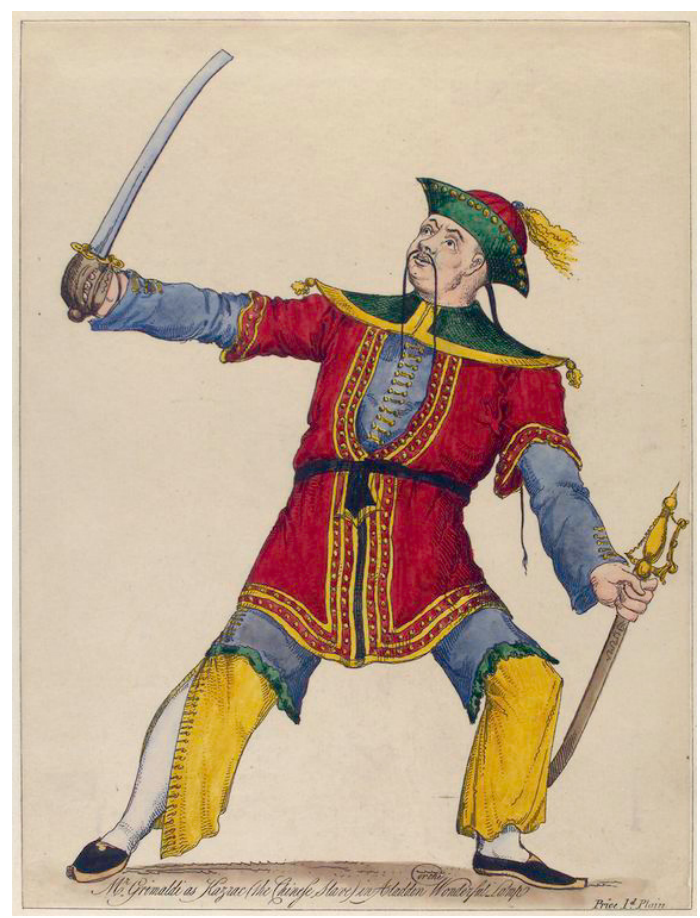

FIGURE 5.2 Mr. Grimaldi as Kazrac (the Chinese slave) in Aladdin, or The Wonderful Lamp.

necklace, earrings, and brooches. With his fanciful hat and long moustache, he depicts a theatrical version of "a Tartar," or "a Man from Crimea." An illustration with the same title was included in an 1804 edition of The Costume of Turkey that aptly associates Kalim Azack with the "Tartarian Hord" responsible for Kazrac's disfigurement. ${ }^{41}$ Kazrac's "Chinese" costume resembles contemporary Qing Dynasty (1636-1912) fashion with its changshan tunic, long, loose trousers, and a cap with upturned brim, topped with a knob. Despite his role as a poor peasant, Kazrac's theatrical costume is embellished with embroidery and a gold trim, and the character wears white stockings. Additionally, Grimaldi sports a braided pigtail and long moustache and brandishes two curved swords. Taken together, these two cultural images exemplify the Orientalized look that contributed to the fantasy

41

"A Tartar. A Man from Crimea," in Octavien Dalvimart, The Costume of Turkey, 1802 (London: Printed for William Miller, 1804), n.p. 
element of the play. An audience of children might be inclined to prefer the poor clown, "Kazrac," in this battle and to notice differences between a powerful figure like Kalim Azack, in his expensive clothing and armour, and a funny, loyal, and voiceless peasant, who could be said to represent childlike innocence and the silent powerlessness of the young.

Aladdin; or, The Wonderful Lamp quickly became a staple among the many publishers of toy theaters, appearing on lists of available titles (often shortened to Aladdin) throughout the nineteenth century. Part of the difficulty for the researcher lies in the limited access to surviving examples of this ephemeral art form, which are often incomplete and yet to be catalogued by major academic databases and bibliographies. Exemplifying the play's popularity, as well as the fractured nature of the archive, the British Museum lists several early sheets depicting the 1813 Aladdin; or, The Wonderful Lamp which duplicate its Orientalized look: one character sheet by Mrs. M. Hebberd dated 1811-1814 featuring ten characters (including Aladdin, twice, in different costumes);42 one sheet featuring scenery and wings for the second scene by J.H. Jameson dated $1813 ;{ }^{43}$ and four scene plates, inlcuding "a street in Cham Tartary," by B. Perkins dated $1813^{-1814}{ }^{44}$ Sets by Orlando Hodgson ${ }^{45}$

42 "One of Hebberd's plates of theatrical characters from the play Aladdin, or the Wonderful Lamp, for the toy theatre," The British Museum, No. 1886, 0513.1849 (London: M. Hebberd, 1811-1814).

43 “Stage scenes for Jameson's toy theatre; including the second scene in Aladdin, with landscape and rock wings," The British Museum, No. 1886, 0513.1781-1791 (London: J.H. Jameson, 1813-1822).

"Four scene plates from the play Aladdin, for Perkins's toy theatre," The British Museum, No. 1886, 0513.18621864 (London: B. Perkins, 1813-1814).

"Four of Hodgson's extra large scenes from Aladdin, for the toy theatre," The British Museum, No. 1886, 0513.1618-1622 (London: Hodgson, 1822); and "Three of Hodgson's scene plates for the play Aladdin, for the toy theatre," The British Museum, No. 1886, 0513.1271-1273 (London: Hodgson, 1823). and William West ${ }^{46}$ were published in 1822-1825; these retain the Orientalized look of the early versions. Later sets not catalogued at the British Museum include John Kilby Green's half-price set (simplified and reprinted from Hodgson's beautiful 1831-1832 set), which was published on January 1, 1841, to accompany the Christmas 1840 revival, and a later (undated) set by M. and B. Skelt. Significantly, all of these sets retain the Orientalized look of the 1813 production. Because publishers regularly acquired each other's inventory of printing plates and repackaged the sheets to sell them under their names, various sets of Aladdin; or, The Wonderful Lamp with its original Orientalized look remained available for decades.

The following discussion centers on Hodgson's 1831-1832 set held by the Victoria and Albert Museum in London, which is the most complete early set of the play readily available online. It includes a playbook, eight character sheets, and thirteen sheets of scenery. ${ }^{47}$ Particularly interesting for our discussion is an apparent interculturalized vision of Arabia, which is visually captured in an Orientalized look that includes a fanciful melding of components derived from contemporary Chinese, Ottoman, North African, and Arabic imagery. As Chang observes, these influences are further "informed by English (British) knowledge about China, Anglo-Chinese relations, English (British) dramatic and theatrical practices, and individual

$46 \quad$ "Eight stage scenes for West's toy theatre, for the play Aladdin, or the Wonderful Lamp," The British Museum, No. 1886, 0513.17-29 (London: William West, 1824). Two other items are catalogued for a play designed by West titled Aladdin, and the Forty Thieves, but the descriptions seem instead to describe scenes for a version of "Ali Baba, and the Forty Thieves," also a popular juvenile and toy theater title of the day; see The British Museum No. 1886, 0513.30, and No. 1886, 0513.1230-1231. [Orlando Hodgson], Aladdin; or the Wonderful Lamp: A Juvenile Drama. Adapted to Hodgson's Scenes and Characters. Playbook, eight character sheets, thirteen scenery sheets. The Victoria and Albert Museum, Theatre Royal Drury Lane Collection, тHM/234/1/8/1 (London: Orlando Hodgson, 1832). 


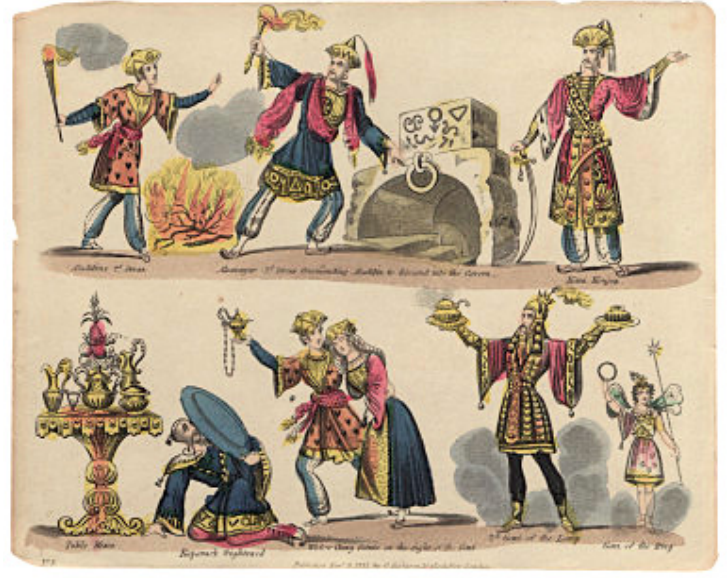

FIGURE 5.3 Hodgson character sheet featuring "Aladdin's 2nd Dress" and others.

PUBLISHED BY O. HODGSON, LONDON, 1831.

creative choices." 48 The script, "A Juvenile Drama," is an adaptation of the 1813 play further "Adapted to Hodgson's Scenes and Characters." The toy theater sheets depict the characters in multiple costumes and dramatic postures, including images that echo the earlier character prints of Kalim Azack and Kazrac, while the scenery represents Romantically desolate locations in "Africa" and "a certain part of Tartary" near "one of the greatest cities in China," complete with buildings resembling pagodas. Rather than evidencing concern for realism or authenticity, this toy theater's Orientalized look, like Aladdin's lamp, offered magic, wonder, and transport to appeal to a young audience.

In toy theater versions like Hodgson's, it is exactly this Orientalized look that appeals in marrying the tale to theatrical spectacle and excitement. Gorgeous scenery and costumes, special effects like the use of "blue fire,"49 melodramatic events like battles, processions, and abductions, and the ready employment of magic and suspended disbelief were the common elements of the most popular

48 Chang, Representing China on the Historical London Stage, 2.

49 This is a flame effect that, along with the miniature theater's tiny oil footlamps, often resulted in unintended conflagrations. toy theater sets, just as they were on the live professional stage. As Liz Farr notes, "[1]ike many of the theatrical productions it represented, the toy [theater] was concerned less with high art than with spectacular forms of entertainment."50 The child proprietors of toy theaters expected and demanded value for their pocket money. Aladdin; or, The Wonderful Lamp regularly satisfied their demands and thus remained on available titles lists well into the twentieth century.

Reimagined in the tiny figures and scenes of the toy theater, Aladdin; or, The Wonderful Lamp offered a wondrous Orientalized look for the child impresario (figs. 5.3 and 5.4). As in the stage play, character names include an interculturalized mix of "Chinese" and "Muslim" names, variously spelled throughout the playbook and on the figural and scenic sheets: Widow Ching Mustapha (Aladdin's mother); Tahi Tongluck, the Cham of Tartary (who is referred to as a "sultan"); Abanazar (the unnamed African magician in Galland's and Scott's versions of the story); Kazrack (the mute Chinese slave); and Zobyad (Princess Balroubadour's servant). Even more interestingly, the characters are costumed in clothes that try to create an "Orientalized" atmosphere. Aladdin (regularly played by an actress) wears a short tunic embellished with hearts and a sash over gathered Ottoman-style trousers. A courtier, Kara Konjou, carries a Persian-inspired scimitar and is richly costumed in an ermine-trimmed long coat with Ottoman trousers and curled-toe Ottoman shoes, as is Abanazar, the African magician. Widow Ching wears her Ottoman-inspired dress with a veil covering her hair. The magnificent second Genie of the Lamp is resplendent in armor that appears to mix Persian and Mongolian elements. The petite Geni of the Ring wears a Grecian-like tunic with wings, a crown, and sandals. This conflation of Turkish or Persian clothing with Arab-style garments is highly indicative of how pervasive these

5o Liz Farr, "Paper Dreams and Romantic Projections: The Nineteenth-Century Toy Theater, Boyhood and Aesthetic Play," in The Nineteenth-Century Child and Consumer Culture, ed. Dennis Denisoff (Aldershot: Ashgate, 2008), 45 . 


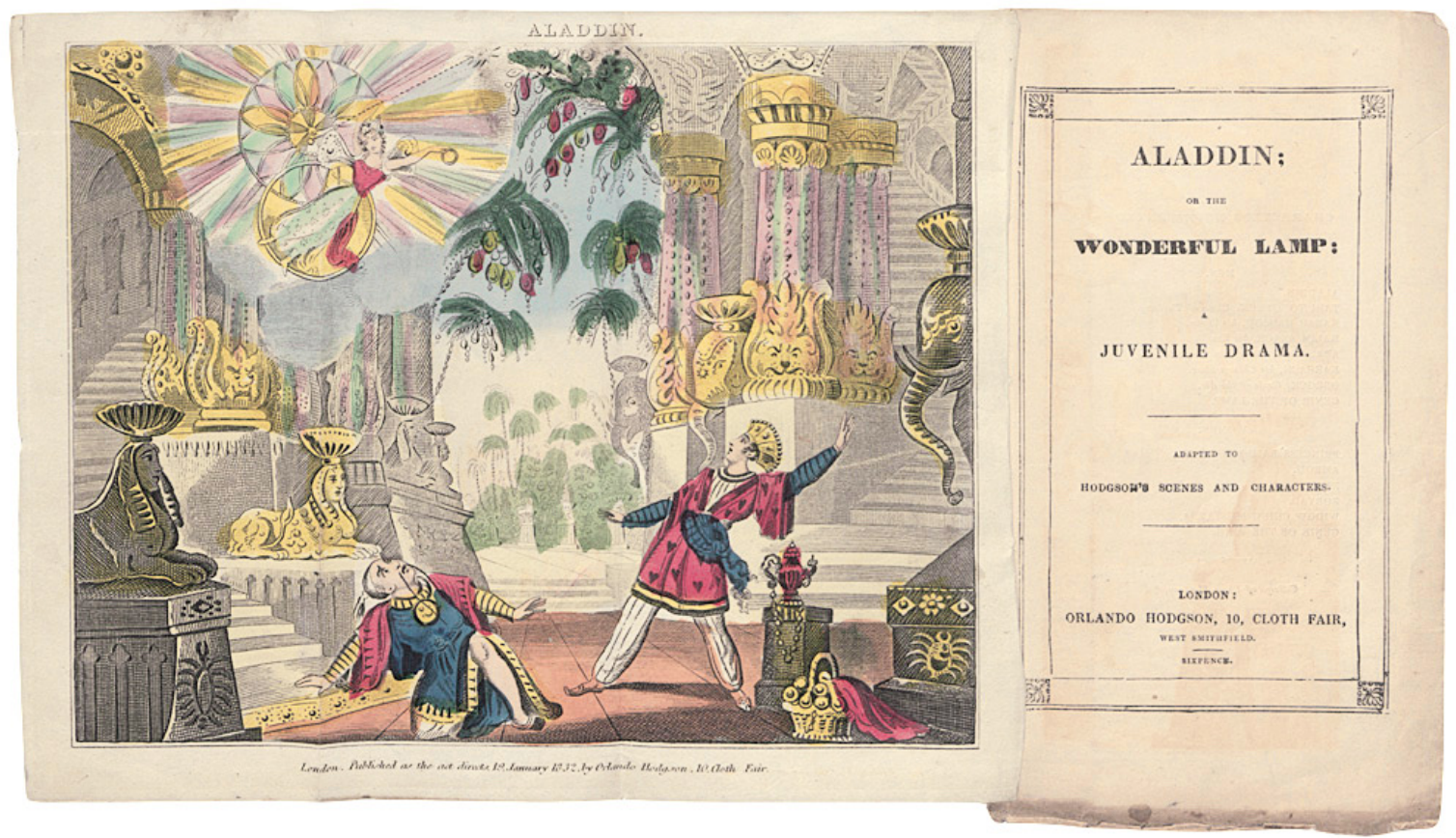

FIGURE 5.4 Hodgson's Scenes in Aladdin, Seventh, including a genie of the ring, Kazrack, and Aladdin in a fantastic setting decorated with elephants, sphinxes, elaborate columns, and trees.

PUBLISHED BY O. HODGSON, LONDON, 1832.

inaccurate representations of "Arabia" were during the nineteenth century.

Often, props and scenery appear on toy theater character sheets. Such is the case here, with the depiction of the crucial scene in which Abanazar is found "Commanding Aladdin to descend into the Cavern." Between them burns Abanazar's magical fire. Abanzar holds a torch to direct Aladdin to the cave's entrance, which features a stone with indecipherable engravings signifying mystery and power. Through the opening, one can see the descending steps. An interesting item on this sheet is a toy theater "trick": the "Table Rises" effect, which would have been a set piece intended to "appear" as if by magic, probably through a stage trap door or pushed on from the wings and perhaps with an accompanying special effect, such as smoke or a flash of light. A scenic image titled "Aladdin" (echoed in a scene titled "Finale in Aladdin") depicts Aladdin's adventure in the cave and, unusually, includes Aladdin and Kazrack gazing in amazement at the Genie of the Ring. Together with the figures in Chinese-like costumes, the scene's Orientalized look is obtained through dramatic carved arches, curving staircases, decorated columns with classical acanthus leaves, trees hanging with jewels for fruits, and statues of elephants and sphinxes lending air an of an Egyptian tomb. ${ }^{51}$ Standing upon its pedestal with a basket of jewels below, the lamp with its glowing flame promises magic.

Aladdin's wonderful lamp was, thus, an essential object that contributed to the spectacular effect depicted on toy theater sheets. As an emblem of material culture, it represents its historical cousins and, like them, it has evolved in form, according to prevailing tastes and technological

Charlotte R. Long comments, "Like Ali Baba and the Forty Thieves, the first part of Aladdin and the Wonderful Lamp describes a tomb robbery.... [but] in the story of Aladdin the subterranean rooms which Aladdin explores are not called a tomb, and their location is veiled by setting the action far off in China" (210). For details, see Charlotte R. Long, "Aladdin and the Wonderful Lamp," Archaeology 9, no. 3 (1956): 210-14. 


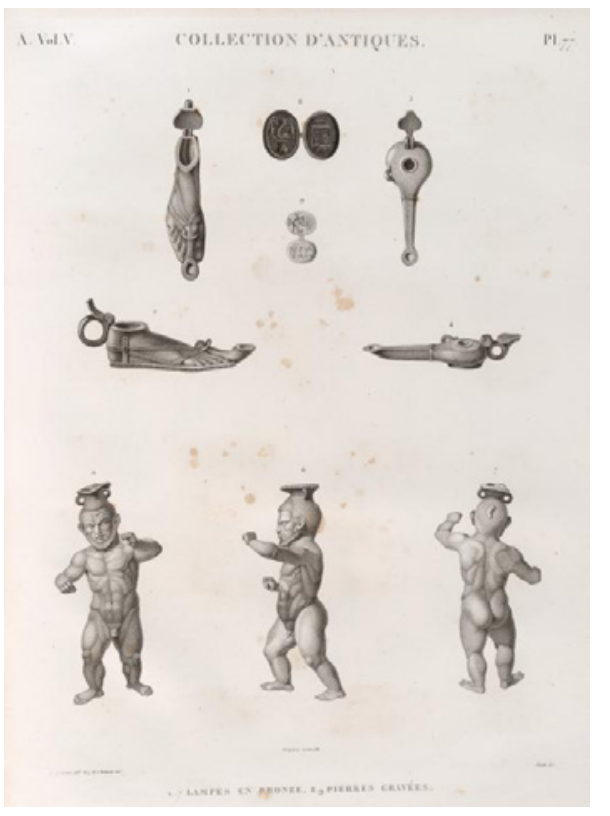

FIGURE 5.5 Collection d'antiques. 1-7. Lampes en bronze; 8.9. Pierres gravées. In Description de l'Égypte

PARIS: DE L'IMPRIMERIE IMPERIALE, 1809-1829.

developments. Early theatrical designers drew upon contemporary collections and source materials and may have consulted repositories such as the British Museum, which from 1805 to 1814 received the Charles Townley collection of antiquarian objects that included dozens of ancient lamps from Townley's multiple grand tours to the continent. Following the 1798 Napoleonic invasion of Egypt, the vast Description de l'Égypte, with its thousands of illustrations, was being readied at this time, reflecting France's imperial ambition toward the people, places, and objects of this ancient land. ${ }^{52}$

As an object depicted on stage and in printed illustrations, the form of Aladdin's lamp was shaped by theatrical requirements, artistic vision, and its historical predecessors, such as the one beautifully illustrated above (fig. 5.5). In the 1810 play, Alladin; or, The Wonderful Lamp, Alladin tells his

52 Description de l'Égypte, ou Recueil des observations et de recherches qui ont été faites en Egypte pendant l'expedition de l'armée française, 23 vols. (Paris: de l'Imprimerie Imperiale, 1809-1829). mother, Zulima, that the lamp "seems to [him] to be brass, ${ }^{53}$ which perhaps prompted theatrical versions resembling gold. In the 1813 set by Hodgson, the characters and scenes look like sketches that might have been made by an artist attending a performance. The lamp can be seen in the form of an urn with a lid and a chain, standing on a pedestal. ${ }^{54}$ With a spout, handle, and chain, the distinctive coffee/teapot-shaped lamp of the $183^{1-183^{2}}$ toy theater sheets became the standard image although, chameleon-like, no two of its depictions in the set are alike. Henry J. Byron's 1861 pantomime Aladdin; or, the Wonderful Scamp! opens in the "Hand-tea room in the Sultan's Palace" with characters drinking tea. The significance of this crucial commodity from China is seen throughout this early modern panto (including character names such as "Widow Twankey" and "Pekoe"). It's possible that the now-familiar slipper-shaped lamp design evolved from an English teapot interculturalized with an ancient oil lamp. Of course, the lamp was supposed to be dirty or in need of polish, to prompt Aladdin's mother's effort to clean it and bring out the genie, but this isn't always evident in the toy theater illustrations.

In a compelling and perhaps irresistible linguistic development, new technology capitalized on the tale in the form of illustrated slides for magic lantern projectors by English companies such as W. Butcher \& Sons (Primus Junior Lecturers Series), York \& Son, and Theobald \& Co. In these visual versions, in tandem with the theatrical evolution of the interculturated story in panto form, the Orientalized (Chinese-British) look took hold and can still be seen in modern panto for children today. Importantly, the magical lamp at the heart of the tale readily found a home in an industry for children's books and toys eager for fabulous material.

\footnotetext{
53 Norwich Mss, 67.

54 The "niche" in which the lamp resided in Galland's and the Grub Street version was often reinterpreted as a "pedestal" for the lamp to sit upon. In theatrical productions, a pedestal could be a handy set piece for making possible the sudden appearance of the genie of the lamp in the scene.
} 


\section{Aladdin's Lamp and Its Twentieth-Century Iterations}

Initially a summoning mechanism that required rubbing to make the genie appear, by the twentieth century Aladdin's lamp had become the genie's residence/prison in films such as Aladdin and His Wonderful Lamp (1939), a two-reel animated film in the Popeye Color Specials Series, The Thief of Bagdad (1940), produced by Alexander Korda, and the full-length animated film Aladdin (1992) by Walt Disney Pictures. In such period films, the genie emerges with the aid of ingenious illustration and special effects, like smoke from the lamp's spout, and is revealed to be a giant. Although the origin of the theatrical lamp's form is unidentifiable, its slipper shape has made it easily recognizable and helped to distinguish it from the many other prop vessels present in various scenes. Its uniqueness comes from its magical properties, which are obvious in moments of exchange. When the magician offers to change a new lamp for an old one, Aladdin's lamp stands out on stage among the many newer lamps as singular, antique, and wonderful. Indeed, Aladdin's lamp could be said to symbolize the magical Arabian tale captured by Galland in the midst of modern appropriation and commodification, surrounded by interculturalized characters and settings with an Orientalized look that, nevertheless, do not resemble its original culture. As a magical vessel in a play for children, it romanticizes Arabia and solidifies sterotypes of the place. As a stage prop, it represents a dream of wealth and exotic travel experiences that would have been impossible for most nineteenth-century children.

As a child growing up in America, I was astonished to learn that the Arabian Nights story of Aladdin and his lamp had long been presented in British panto and set in China. I had not yet read an authoritative version of the tale, and this cultural difference puzzled me until I learned that my struggle was due to the indelible spell wrought by Walt Disney Pictures' 1992 full-length animated film Aladdin, which invokes the now centuries-old effort to recover a "more authentic" vision of
Arabia in the late twentieth century's own compass rose event of the evolving portolan map of Aladdin's history. Starring Scott Weinger as Aladdin, Linda Larkin as Princess Jasmine, and Robin Williams as the Genie, Aladdin may be the most influential of the children's versions to date due to its worldwide release and afterlife. The exuberant narrative of the 1992 Aladdin draws upon The Thief of Bagdad, but it also returns to the original tale to craft an elaborate recounting of the retrieval of the lamp from the cave and the magician's removal of the princess and the palace to a faraway land. The lamp is rendered in its traditional slipper shape and forms the basis for the design of the magical flying carpet. Costumes approximate Middle Eastern styles (with Jasmine notable in a harem-type outfit), although the sultan's palace design is derived from the Taj Mahal in India. A nod to Aladdin's Chinese roots is seen in the final location of the sequence accompanying the signature song, "A Whole New World," when Aladdin and Jasmine arrive at a palace complex resembling Beijing's Forbidden City. This Disneyfied combination of cultural elements presents an American Orientalized look. Not only has the film remained available in recorded editions, theatrical and television re-release, and licensing agreements for books, toys, and more but also has engendered what Irwin calls an "autocannibalistic" version, a live action film based on the animated one and released in 2019. ${ }^{55}$ Also titled Aladdin, the main roles are played by Mena Massoud (Aladdin), Naomi Scott (Princess Jasmine), and Will Smith (Genie). The 2019 Aladdin largely parallels its predecessor but dazzles with elaborate production numbers, particularly Aladdin's procession to the palace. One notable change is the frame story of a father telling the tale to his children. At the end, he is revealed to be the genie, who has married - and grown old with-Jasmine's maid, Dalia.

Similarly, modern panto, exemplified by Simon Nye's 2000 Alladin production for ITV, carries forward to the twenty-first century cultural elements

55 Irwin, "A Thousand and One Nights at the Movies," 228. 

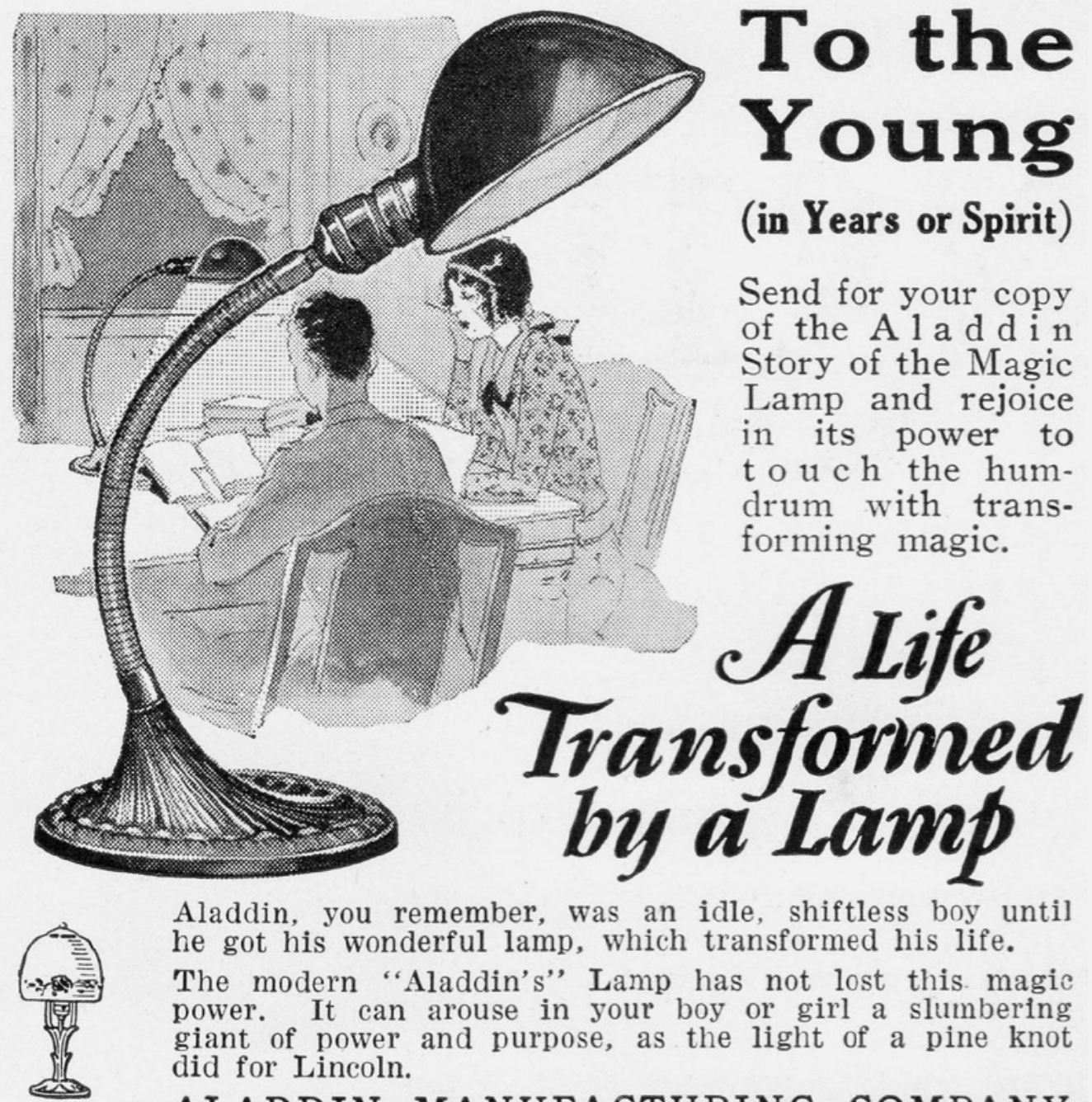

Aladdin, you remember, was an idle, shiftless boy until he got his wonderful lamp, which transformed his life. The modern "Aladdin's" Lamp has not lost this magic power. It can arouse in your boy or girl a slumbering giant of power and purpose, as the light of a pine knot did for Lincoln.

ALADDIN MANUFACTURING COMPANY Sales Div. 19, Muncie, Indiana (The Magic City)
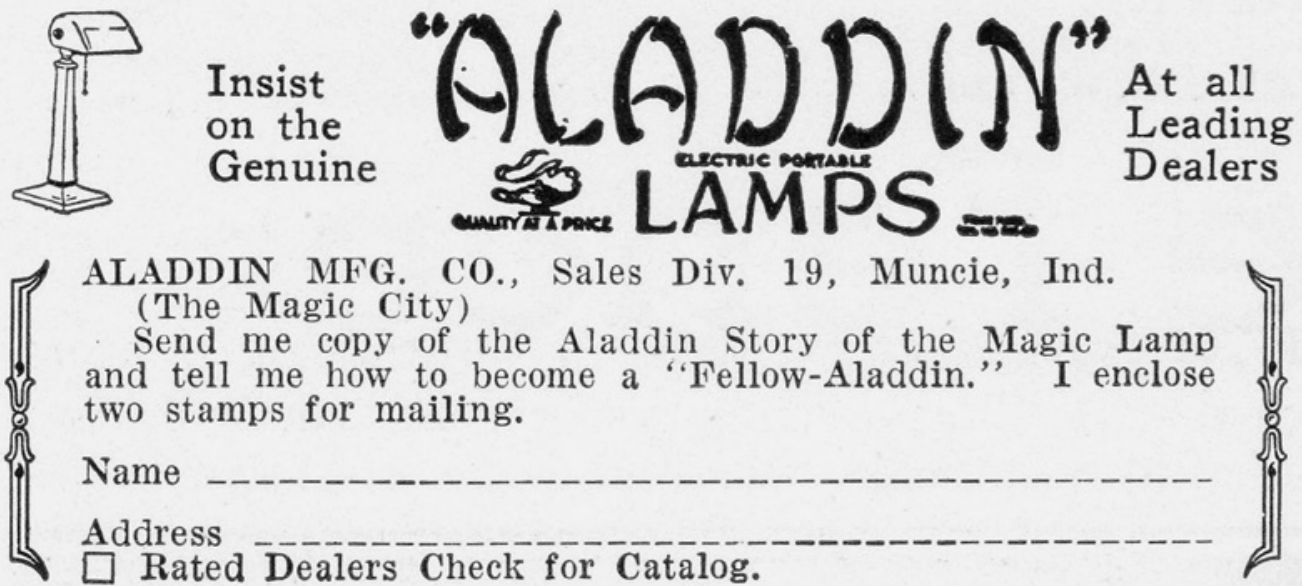

FIGURE 5.6 Aladdin Magic Lamp Story Ad, 1927. 
of the story's earliest British versions: interculturalized Chinesely-British characters and settings in China (Peking), an Egyptian tomb with a diabolical walking mummy, and a magical cave that is a nod to India, all combining for a continued Orientalized look. Lost in both of these traditions is a genuine sense of Arabia; however, the richness of Aladdin's story has always lain in its capacity to entertain and create wonder about a fantastical place that becomes a matrix of original tale, reinterpretation, and imaginative visualization.

In a notable compass rose event, the story of Aladdin and his wonderful lamp took an interesting turn at the beginning of the twentieth century, when, as Victor S. Johnson, founder of the Mantle Lamp Company of America, recalls:

“(...) a very small boy [Johnson] on a Nebraska farm read and re-read the Arabian Nights story of Aladdin in a room of darkness but for the flickering yellow light of an open flame 'coal oil lamp.' Several years later that boy, grown to manhood, found a lamp that erased the darkness with a soft white light and it was only natural that he named the lamp 'Aladdin.' An appropriate name, indeed, for this revolutionary boon to rural America seemed nothing short of magical in the intensity of its light." 56

While the story may be apocryphal, "Aladdin" lamps proved invaluable to households across America and were touted as improving children's education by enabling them to attend to their studies after rural chores had been completed. Claiming early on to be "The Best Rural Home Lamps in the World," Aladdin lamps (also known as "Aladdins") have been manufactured from 1908 to the present, evolving with technological advances and often driving them in the industry (fig. 5.6). In an enticing move, a 1927 advertisement addressed "To the Young (in Years or Spirit)" invited readers to "[s] end for your copy of the Aladdin Story of the

56 J.W. Courter, A Brief History of Aladdin Lamps (Chicago: Mantle Lamp Company of America, 2002), n.p.
Magic Lamp and rejoice in its power to touch the humdrum with transforming magic." Depicting an up-to-date "goose-neck lamp," the company alerted readers that the "modern 'Aladdin's Lamp' has not lost this magic power. It can arouse in your boy or girl a slumbering giant of power and purpose, as the light of a pine knot did for Lincoln." Aligning an Aladdin Lamp's power with Abraham Lincoln's invested it with American patriotism and twentiethcentury education-based vigor, making of the tale's magical lamp a beacon for the future in a distinctly American way.

\section{Conclusion}

This chapter has considered the evolution of the tale "Aladdin; or the Wonderful Lamp" as entertainment for children in Britain and America, with a focus on the lamp as a material object and nexus of dreams about an exoticised Arabia connoting magic, wealth, and joy. Like the tracery of a portolan map, the tale and the lamp move through time and place, generating compass rose events when they transform and are transformed by cultural engagement and appropriation. These events included the first translation of Les mille et une nuits into French, then English, then to the stage, the juvenile drama and toy theater, a brief consideration of twentieth-century film and panto, which along with the evolution of Aladdin portable lamps bear the tale into modern times. All these cultural elements reveal a continuing and diverse interculturation pictured in varying Orientalized looks, each culminating in culturally infused fantasies gesturing at literary authenticity and representing either the setting of Scheherezade's tale-telling (Arabia) or the settings named in the original story (China and Africa). The two approaches diverge geographically and visually, with English signifiers of British imperial history in China, India, and Africa, and American signifiers of its complex relationship with the Middle East. Driving these two traditions are historical circumstances involving cultural 
contact and trade beyond the scope of this discussion but ready for further investigation.

In Findlen's terms, the nodal lamp as physical object, "becomes a material interface, a repository of social and economic exchange as well as a bearer of cultural meaning that can be subject to physical inspection and analysis." ${ }^{.57}$ As a material and symbolic object, as well as a detachable "character" signifying a story, Aladdin's lamp aptly illustrates this description: it is a repository for oil, which can be burnt and transformed into light, vanquishing darkness and fear and making possible vision and creation with its inherent property of illumination. Aladdin's lamp has also become a unique signifier for the boy Aladdin, the genie, the tale itself, a culture of wish-fulfillment, and the entire Arabian Nights'Entertainments compendium. Horta points to folklore scholar Ulrich Marzolph's coining of the term "Aladdin Syndrome": "the tendency to use this story to represent the Thousand and One Nights, Arabic literature, and Middle Eastern cultures as a whole." 58 Its magic conjures an Orientalized Arabia that is textually interculturated and visually exoticized, a representation that persists to this day although it has little to do with the actual place. Indeed, a quick online search for "image Aladdin lamp" renders many results of Aladdin lamps by Johnson's Mantle Lamp Company of America, with their glass chimneys, urn-shaped pedestals, and curved glass lampshades. More images by far, however, are of slipper-shaped lamps with a handle, often made of brass resembling gold and highly decorated, all hinting at a touch of the magic of Arabia.

$5^{8}$ Horta, "Introduction," xviii. 